\title{
Building Soil Health, Improving Carbon Footprint and Minimizing Greenhouse Gas Emissions through CSR
}

\author{
Girish Chander, ${ }^{*}$ Suhas P. Wani, G. Pardhasaradhi, \\ MuKund D. Patil and A.N. RaO
}

International Crops Research Institute for the Semi-Arid Tropics, Patancheru, India

\begin{abstract}
Unabated soil degradation due to low soil organic carbon (C) levels, multiple nutrient deficiencies including micro- and secondary nutrients, rising salinity and soil loss due to erosion jeopardizes food security of swiftly rising global population projected to be 9.7 billion by 2050 . Soils also play a major role in global $\mathrm{C}$ cycling and huge $\mathrm{C}$ sequestration potential offers opportunities for mitigating carbon dioxide and other greenhouse gas emissions. The lessons learnt from CSR pilot and scaling-up initiatives indicated significant productivity benefits with soil health mapping-based management. The linkages of soil health and food quality are documented. Soil mapping-based management increased $\mathrm{C}$ sequestration with higher proportion of biomass $\mathrm{C}$ and enhanced uptake and use efficiency of nitrogen fertilizers, and thereby reducing losses through runoff and gaseous emissions. Management at watershed level is proved as one of the most trusted approach to managing natural resources and reducing runoff, soil loss and $\mathrm{C}$ and nutrients therein.
\end{abstract}

\subsection{Why Soil Health, Carbon and Greenhouse Gases are Important}

Soils are fundamental to life on Earth and careful soil management is one essential element of sustainable agriculture and also a valuable lever for climate regulation and a pathway for safeguarding ecosystem services. Soils provide ecosystem services categorized into four broad classes: provisioning; regulating; supporting; and cultural services (Table 3.1). Provisioning services refer to the products obtained of direct benefit to people; regulating services to the benefits obtained from the regulation of ecosystem processes; supporting services are necessary for the production of all other ecosystem services (their impacts on people are often indirect or occur over a very long time); and cultural services refer to non-material benefits which people obtain from ecosystems (FAO and ITPS, 2015).

As defined in the World Soil Charter, sustainable soil management comprises activities that maintain or enhance the supporting, provisioning, regulating and cultural services provided by soils without significantly impairing either the soil functions that enable those

\footnotetext{
* Corresponding author: g.chander@cgiar.org
} 
Table 3.1. Ecosystem services provided by the soil, and soil functions that support these services. From: FAO and ITPS (2015).

\begin{tabular}{|c|c|}
\hline Ecosystem service & Soil function \\
\hline \multicolumn{2}{|l|}{ Provisioning } \\
\hline Food supply & $\begin{array}{l}\text { Providing water, nutrients and physical support for growth of plants } \\
\text { for human and animal consumption }\end{array}$ \\
\hline Fibre and fuel supply & $\begin{array}{l}\text { Providing water, nutrients and physical support for growth of plant for } \\
\text { bioenergy and fibre }\end{array}$ \\
\hline Refugia & Providing habitat for soil animals, birds, etc. \\
\hline Genetic resources & Source of unique biological materials \\
\hline Raw earth material supply & Provision of topsoil, aggregates, peat, etc. \\
\hline Surface stability & Supporting human habitations and related infrastructure \\
\hline Water supply & Retention and purification of water \\
\hline \multicolumn{2}{|l|}{ Regulating } \\
\hline Climate regulation & Regulation of $\mathrm{CO}_{2}, \mathrm{~N}_{2} \mathrm{O}$ and $\mathrm{CH}_{4}$ emissions \\
\hline Water quality regulation & $\begin{array}{l}\text { Filtering and buffering of substances in soil water } \\
\text { Transformation of contaminants }\end{array}$ \\
\hline Water supply regulation & $\begin{array}{l}\text { Regulation of water infiltration into soil and water flow within the soil } \\
\text { Drainage of excess water out of soil and into groundwater and surface } \\
\text { water }\end{array}$ \\
\hline Erosion regulation & Retention of soil on the land surface \\
\hline \multicolumn{2}{|l|}{ Supporting } \\
\hline Soil formation & $\begin{array}{l}\text { Weathering of primary minerals and release of nutrients } \\
\text { Transformation and accumulation of organic matter } \\
\text { Creation of structures (aggregates, horizons) for gas and water flow } \\
\text { and root growth } \\
\text { Creation of charged surfaces for ion retention and exchange }\end{array}$ \\
\hline Nutrient cycling & $\begin{array}{l}\text { Transformation of organic materials by soil organisms } \\
\text { Retention and release of nutrients on charged surfaces }\end{array}$ \\
\hline Primary production & $\begin{array}{l}\text { Medium for seed germination and root growth } \\
\text { Supply of nutrients and water for plants }\end{array}$ \\
\hline \multicolumn{2}{|l|}{ Cultural } \\
\hline Aesthetic and spiritual & $\begin{array}{l}\text { Preservation of natural and cultural landscape diversity } \\
\text { Source of pigments and dyes }\end{array}$ \\
\hline Heritage & Preservation of archaeological records \\
\hline
\end{tabular}

services or biodiversity. Major threats to soil functions include nutrient imbalances, soil organic carbon (C) loss, soil erosion, salinization, soil acidification, soil contamination, soil compaction, waterlogging, soil sealing and loss of soil biodiversity.

In recent times, increasing land degradation is one of the major challenges and debatable topic. 'Land degradation' refers to a temporary or permanent decline in the productive capacity of the land, or its potential for environmental management. The most important on-farm effects of land degradation are declining potential yields or need to use a higher level of inputs in order to maintain yields. The unabated land degradation jeopardizes food security of swiftly rising population. The world population of 7.2 billion in mid-2013 is projected to increase to 8.2 billion by $2025,9.7$ billion by 2050 , and to rise to 10.9 billion by 2100 (UN, 2016). Carbon storage is an important ecosystem function of soils that has gained increasing attention in recent years due to its direct relation with soil health and mitigation potential of greenhouse gases (GHGs). There are major opportunities for mitigation of carbon dioxide $\left(\mathrm{CO}_{2}\right)$ and other $\mathrm{GHG}$ emissions through changes in the use and management of agricultural lands by maintaining or increasing stocks of organic C in soils (and biomass), and reduced emissions by the agricultural sector itself (Paustian et al., 1998; Whitmore et al., 2014). Inefficient nitrogen $(\mathrm{N})$ fertilizer-related pollution is an issue of concern worldwide. Nitrogen fertilizer inputs in excess of crop requirements are 
linked to the enhanced release of nitrous oxide $\left(\mathrm{N}_{2} \mathrm{O}\right)$, a GHG 300 times more potent than $\mathrm{CO}_{2}$, and agricultural soils are the dominant source, contributing over $80 \%$ of global anthropogenic $\mathrm{N}_{2} \mathrm{O}$ emissions during the 1990s. Nitrous oxide emissions from agricultural soils are projected to increase from just over four million tons $\mathrm{N}_{2} \mathrm{ON}$ per year in 2010 to over 5 million tons $\mathrm{N}_{2} \mathrm{O}$ N per year by 2030 .

The impact of land degradation is especially severe on livelihoods of the poor who heavily depend on natural resources. The annual cost of land degradation at the global level was about US $\$ 300$ billion (Nkonya et al., 2016). Sub-Saharan Africa accounts for the largest share (22\%) of the total global cost of land degradation. The analysis of the cost of land degradation across the type of ecosystem services shows that $54 \%$ of the cost is due to the losses in regulating, supporting and cultural services which are considered as global public goods. And hence reversing land degradation trends while improving $\mathrm{C}$ footprints and reducing GHG emissions definitely makes economic sense with multiple social and environmental benefits.

\subsection{How Soil Health and Ecosystem Service Issues are Aggravated}

According to the National Bureau of Soil Survey and Land Use Planning (2005) assessment during 2004, 146.8 million ha is degraded. Erosion is the most serious degradation problem in India covering around 93.7 million ha under water erosion and 9.5 million ha under wind erosion. Inappropriate land and water management practices in agriculture along with other human interventions like land clearing and careless management of forests, deforestation, overgrazing, surface mining, industrial development, etc. contribute to erosion problem. Further, in the post-Green Revolution era, nutrient mining along with imbalanced use of fertilizers has created multiple nutrient deficiencies which threaten sustainability. Soil fertility degradation coupled with indiscriminate use of $\mathrm{N}$ fertilizers is a major factor for low $\mathrm{N}$ use efficiency and losses in runoff and as GHG emission. Imbalanced use of fertilizers arises due to fertilizer subsidy, inadequate availability of the required fertilizers at the stipulated time in rural areas and lack of knowledge among farmers as to what nutrients are required by the crops and what is missing in their land. Due to cheaper chemical fertilizers, farmers have moved away from using organic manures, which has led to depletion of soil organic $\mathrm{C}$ also. The public infrastructure for soil analysis is also poorly developed and farmers rarely get quality information in time. A fragmented approach to soil analysis has restricted analysis to only macronutrients. Over-exploitation of groundwater has also emerged as one of the major factors contributing to secondary salinization. Out of 42 million ha irrigation through groundwater sources in the country, the surveys indicate that poor-quality waters being utilized in different states are $32-84 \%$ of the total groundwater development (Dagar, 2005). Such increase in irrigated area as envisaged would lead to secondary salinization consequentially leading to estimated 16.2 million ha salt affected area by 2050 .

\subsection{Soil Degradation Challenges in General and in CSR Sites}

Increasing soil degradation, if not addressed properly, poses grave challenge to the realization of ambitious Sustainable Development Goals (SDGs), a set of seventeen aspirational 'Global Goals' with 169 targets between them (Wani et al., 2015; UN, 2017). The SDGs came into effect in January 2016 and are largely interconnected. Soil degradation and related issues pose direct challenges in realization of certain goals like - no poverty; zero hunger; good health and well-being; clean water and sanitation; climate action; and life on land.

At global scale, out of 8.7 billion ha of agricultural land, pasture, forest and woodland, nearly 2 billion ha (22.5\%) have been degraded since mid-century (Scherr and Yadav, 1996). Nearly half of this vegetated area is under forest, of which about $18 \%$ is degraded; 3.2 billion ha are under pasture, of which $21 \%$ is degraded; and nearly 1.5 billion ha are in cropland, of which $38 \%$ is degraded. Overall, water erosion is the principal cause of degradation and wind erosion is an important cause in drylands and areas with landforms conducive to high winds. 
Chemical degradation such as nutrient loss and salinization, a result of cropping practices, accounts for a smaller overall proportion of degraded lands, but more than $40 \%$ of cropland degradation. Degradation of cropland appears to be most extensive in Africa, affecting $65 \%$ of cropland area, compared with $51 \%$ in Latin America and 38\% in Asia (Scherr and Yadav, 1996).

The pilot studies supported by seven corporate social responsibility (CSR) projects across eight states in India, viz. Andhra Pradesh, Jharkhand, Karnataka, Madhya Pradesh, Maharashtra,
Odisha, Rajasthan and Telangana (Fig. 3.1), showed still higher soil degradation compared to in general $40 \%$ of cropland degradation globally under chemical degradation (Table 3.2). Soil organic $\mathrm{C}$ is an indicator of general soil health and most fields (5-87\% fields with low C levels across pilot sites) are detected with low soil organic C. Low soil organic $\mathrm{C}$ also indicate $\mathrm{N}$ deficiency. Available phosphorus (P) deficiency ranged between $10 \%$ and $89 \%$, while potassium $(\mathrm{K})$ is not an issue of concern in most fields adequate in it except pilot sites in Jharkhand. Along with macronutrients, there are widespread

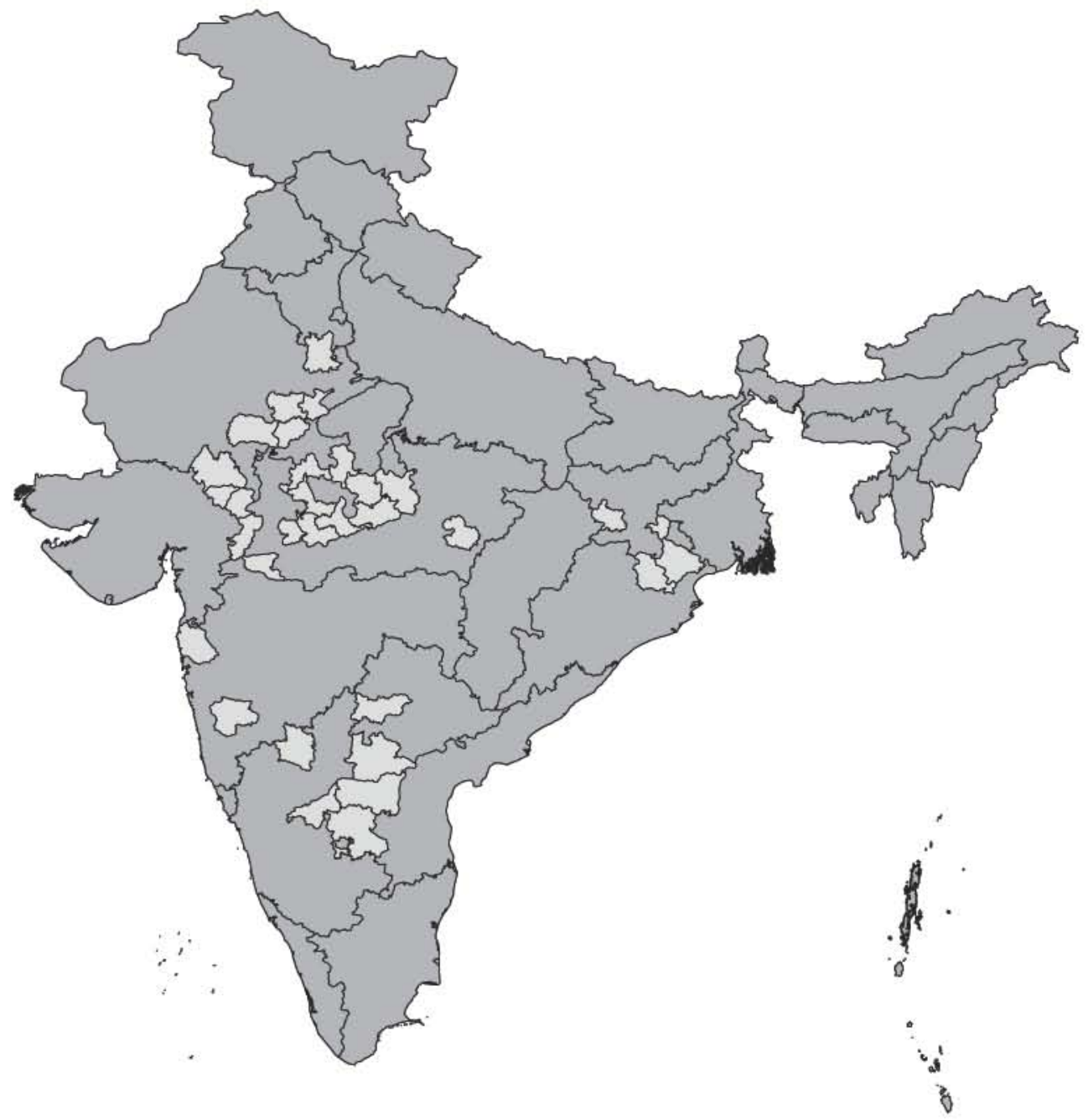

Fig. 3.1. Pilot sites supported under CSR projects across eight states in India: Andhra Pradesh, Jharkhand, Karnataka, Madhya Pradesh, Maharashtra, Odisha, Rajasthan and Telangana. 
Table 3.2. Percentage of farm fields found deficient in available nutrients and having low levels of soil organic carbon (C) across CSR pilot sites in India.

\begin{tabular}{|c|c|c|c|c|c|c|c|c|c|c|c|c|c|c|c|c|c|}
\hline \multirow[b]{2}{*}{ CSR project } & \multirow[b]{2}{*}{ State } & \multirow[b]{2}{*}{ District } & \multirow[b]{2}{*}{ MandaV/Taluk/Block } & \multirow{2}{*}{$\begin{array}{c}\% \\
\text { samples } \\
\text { with low } \\
\text { soil org C }\end{array}$} & \multirow[b]{2}{*}{$\mathrm{pH}$} & \multirow[b]{2}{*}{$\begin{array}{c}\mathrm{EC} \\
(\mathrm{dS} / \mathrm{m})\end{array}$} & \multicolumn{10}{|c|}{$\%$ deficiency } & \multirow[b]{2}{*}{$\begin{array}{l}\text { No. of } \\
\text { samples }\end{array}$} \\
\hline & & & & & & & $P$ & $\mathrm{~K}$ & $\mathrm{~s}$ & $\mathrm{Ca}$ & $\mathrm{Mg}$ & $\mathrm{Zn}$ & B & $\mathrm{Fe}$ & $\mathrm{Cu}$ & $\mathrm{Mn}$ & \\
\hline Asian Paints & Telangana & Medak & Patancheru & 59 & 8.06 & 0.44 & 10 & 0 & 35 & 1 & 0 & 62 & 19 & 1 & 0 & 0 & 189 \\
\hline Asian Paints & Maharashtra & Satara & Khandala & 52 & - & 0.20 & 26 & 3 & 80 & 0 & 0 & 76 & 67 & 5 & 0 & 0 & 324 \\
\hline $\begin{array}{l}\text { Jindal South } \\
\text { West Steel Ltd }\end{array}$ & Karnataka & Bellary & Sandur & 35 & 8.0 & 0.24 & 30 & 0 & 55 & - & - & 67 & 23 & 15 & 8 & 0 & 879 \\
\hline $\begin{array}{l}\text { Jindal South } \\
\text { West Steel Ltd }\end{array}$ & Maharashtra & Palghar & Jawhar & 5 & 6.13 & 0.12 & 43 & 3 & 57 & 0 & 0 & 27 & 57 & 0 & 0 & 0 & 95 \\
\hline $\begin{array}{l}\text { Rural Electrification } \\
\text { Corporation Ltd }\end{array}$ & Telangana & Mahabubnagar & Wanaparthy & 81 & 7.71 & 0.12 & 46 & 14 & 83 & 38 & 1 & 81 & 73 & 10 & 0 & 39 & 192 \\
\hline $\begin{array}{l}\text { Rural Electrification } \\
\text { Corporation Ltd }\end{array}$ & $\begin{array}{l}\text { Andhra } \\
\text { Pradesh }\end{array}$ & Anantapur & Penukonda & 87 & 7.93 & 0.19 & 69 & 15 & 77 & 29 & 0 & 94 & 77 & 7 & 0 & 44 & 190 \\
\hline POWERGRID & $\begin{array}{l}\text { Andhra } \\
\text { Pradesh }\end{array}$ & Kurnool & Bethamcherla & 50 & 7.48 & 0.19 & 15 & 8 & 76 & 80 & 0 & 75 & 35 & 4 & 0 & 12 & 169 \\
\hline POWERGRID & Karnataka & Bijapur & Basavan Bagewadi & 49 & 8.16 & 0.27 & 89 & 0 & 71 & 0 & 0 & 94 & 16 & 8 & 0 & 0 & 187 \\
\hline SABMiller & Telangana & Medak & Pulkal, Sangareddy & 71 & 7.76 & 0.29 & 28 & 6 & 55 & 6 & 0 & 66 & 45 & 0 & 0 & 2 & 246 \\
\hline $\begin{array}{l}\text { Sir Dorabji Tata } \\
\text { Trust }\end{array}$ & Rajasthan & $\begin{array}{l}\text { Alwar, Banswara, } \\
\text { Bhilwara, Bundi, } \\
\text { Dungurpur, } \\
\text { Jhalawar, Swai } \\
\text { Madhopur, Tonk, } \\
\text { Udaipur }\end{array}$ & $\begin{array}{l}\text { Rajgarh, Kushalgarh, } \\
\text { Jahajapur, Hindoli, } \\
\text { Bichiwara, } \\
\text { Jhalarapatal, } \\
\text { Khandar, Deoli, } \\
\text { Newai, Girwa }\end{array}$ & 38 & 7.8 & 0.3 & 45 & 15 & 71 & - & - & 46 & 56 & - & - & - & 422 \\
\hline Sir Ratan Tata Trust & Jharkhand & Gumla, Kharsawan & Raidih, Saraikala & 42 & 5.6 & 0.15 & 65 & 50 & 77 & - & - & 71 & 97 & - & - & - & 115 \\
\hline $\begin{array}{l}\text { Sir Dorabji Tata } \\
\text { Trust \& Sir Ratan } \\
\text { Tata Trust }\end{array}$ & $\begin{array}{l}\text { Madhya } \\
\text { Pradesh }\end{array}$ & $\begin{array}{l}\text { Badwani, Dewas, } \\
\text { Guna, Indore, } \\
\text { Raisen, Rajgarh, } \\
\text { Sagar, Sehore, } \\
\text { Shajapur, } \\
\text { Vidisha, Jhabua, } \\
\text { Mandla }\end{array}$ & $\begin{array}{l}\text { Badwani, Devas, } \\
\text { Madusudangarh, } \\
\text { Samer, Silwani, } \\
\text { Rajgarh, JC Nagar, } \\
\text { Sehore, Agar, } \\
\text { Vidisha, Lateri, } \\
\text { Meghnagar, Niwas }\end{array}$ & 22 & 7.8 & 0.25 & 74 & 1 & 74 & - & - & 66 & 79 & - & - & - & 341 \\
\hline Sir Ratan Tata Trust & Odisha & $\begin{array}{l}\text { Myurbhanj, } \\
\text { Kyonjhar }\end{array}$ & $\begin{array}{l}\text { Myurbhanj, } \\
\text { Harichandanpur }\end{array}$ & 18 & 5.5 & 0.12 & 73 & 10 & 96 & - & - & 7 & 99 & - & - & - & 177 \\
\hline
\end{tabular}


deficiencies of secondary and micronutrients like $35-96 \%$ in sulfur (S), 16-99\% in boron (B) and $7-94 \%$ in zinc $(\mathrm{Zn})$, and $0-80 \%$ in calcium (Ca).

Most farmers are not aware of secondary and micronutrient deficiencies and their general practice is to add fertilizers containing only macronutrients NPK in suboptimal or indiscriminate amounts, which creates nutrient imbalances leading to increasing land degradation. Even with regard to macronutrients, the government fertilizer subsidy policy has promoted skewed fertilizer use in the country resulting in more application of $\mathrm{N}$ and $\mathrm{P}$ fertilizers in the NPK ratio of 8:2.7:1 (Government of India, 2014; Wani et al., 2016). Inadequate availability of the required fertilizers at the stipulated time in rural areas and lack of knowledge is also promoting imbalanced fertilizer use. More importantly, while fertilizer consumption continues to rise substantially, the elasticity of output with respect to fertilizer use, especially $\mathrm{N}$ and $\mathrm{P}$, has dropped sharply, i.e. declining fertilizer use efficiency. During the previous decade, while fertilizer consumption grew by $50 \%$, the increase in food grain production was only $11 \%$ (Wani et al., 2016). The increase in fertilizer use has increased the cost significantly. The fiscal burden of fertilizer subsidy was ₹ 60 crore in the years 1976-77, which shot up to over ₹70,000 crore in 2012-13. There are other important costs in the form of long-term soil degradation and stagnation of yields, low C-sequestration and degradation of water resources (in both quantity and quality). Besides, there is build-up of nutrients in pockets which is of concern today.
Along with agricultural fields, horticultural orchards and plantation crops also cover large tracts of land and are bypassed for any systematic soil health mapping and needsbased management. These are potential sites of increasing productivity and incomes, while improving $\mathrm{C}$-footprints. For example, soil health mapping of fruit and plantation crops in Andhra Pradesh showed severely low levels of soil organic $\mathrm{C}$ and increasing nutrient deficiencies $-42-90 \%$ orchards/plantations in organic C, $3-70 \%$ in P, $1-40 \%$ in $\mathrm{K}, 10-89 \%$ in $\mathrm{Ca}, 21-96 \%$ in $\mathrm{S}, 18-80 \%$ in $\mathrm{Zn}, 8-85 \%$ in $\mathrm{B}$, $0-45 \%$ in magnesium $(\mathrm{Mg})$ and $0-63 \%$ in copper (Cu) (Table 3.3).

\subsection{Building Soil Health and Ecosystem Services: A Low Hanging Technology}

\subsubsection{Soil health for food and nutritional security}

One of the direct benefits that CSR scaling-up initiatives have demonstrated is improving food security. The strategies to rejuvenate farm soil health have shown significant productivity benefits that varied from $25 \%$ to $47 \%$ in cereals, $28 \%$ to $37 \%$ in pulses and $22 \%$ to $48 \%$ in oilseed crops (Chander et al., 2016; Wani and Chander, 2016; Wani et al., 2017). Even in comparatively drier years, soil health building through application of balanced fertilizers significantly increases grain yield and aboveground dry matter and adds to system resilience (Uppal et al., 2015). Pilot

Table 3.3. Soil fertility status of soils in horticulture plantations across seven districts in Andhra Pradesh, India.

\begin{tabular}{|c|c|c|c|c|c|c|c|c|c|c|c|c|}
\hline \multirow[b]{2}{*}{ Crop } & \multirow[b]{2}{*}{ No. of samples } & \multirow{2}{*}{$\begin{array}{l}\% \text { samples with } \\
\text { low soil C levels }\end{array}$} & \multicolumn{10}{|c|}{$\%$ deficiency of available nutrients } \\
\hline & & & $\mathbf{P}$ & $\mathrm{K}$ & $\mathrm{Ca}$ & $\mathrm{Mg}$ & S & $\mathrm{Zn}$ & B & $\mathrm{Fe}$ & $\mathrm{Cu}$ & Mn \\
\hline East Godavari & 720 & 76 & 63 & 36 & 81 & 9 & 88 & 64 & 71 & 0 & 37 & 2 \\
\hline Guntur & 264 & 42 & 3 & 1 & 10 & 0 & 21 & 18 & 8 & 4 & 0 & 0 \\
\hline Krishna & 2709 & 68 & 25 & 2 & 80 & 1 & 79 & 59 & 38 & 0 & 33 & 0 \\
\hline Srikakulam & 641 & 90 & 41 & 40 & 89 & 45 & 95 & 59 & 85 & 1 & 63 & 1 \\
\hline Visakhapatnam & 207 & 77 & 49 & 8 & 65 & 5 & 85 & 54 & 68 & 0 & 14 & 0 \\
\hline Vizianagaram & 869 & 89 & 70 & 26 & 71 & 14 & 96 & 80 & 83 & 0 & 18 & 0 \\
\hline West Godavari & 623 & 77 & 21 & 32 & 79 & 21 & 80 & 41 & 72 & 2 & 42 & 1 \\
\hline Grand total & 6033 & 74 & 37 & 16 & 76 & 11 & 82 & 59 & 56 & 1 & 33 & 0 \\
\hline
\end{tabular}


studies also show evidences of relation of soil health with food quality (Sahrawat et al., 2008, 2013; Chander et al., 2013a; Wani and Chander, 2016). Moreover, the outcome of soil degradation in predominant crop-livestock farming system in the drylands is far beyond reducing grain production; it also affects livestock feed quantity and quality (Blümmel et al., 2009; Haileslassie et al., 2011). In view of the increasingly important role of crop residue as feed components, the effects of soil health building through nutrient balancing on feed availability and feed quality are very important and show up in potential milk yield per ha by as high as $40 \%$ (Haileslassie et al., 2013). The role of soil health building in enhancing food quantity and quality and helping individuals and communities to build sustainable food security is well demonstrated in Karnataka, India (Wani et al., 2016).

Scaling-up soil health building in degraded drylands is important because out of 1.5 billion ha of cultivated land globally, about 1.1 billion ha $(80 \%$ of world's physical agricultural area) is rainfed and generates about $60 \%$ of the world's staple food (Munir et al., 2010). Evidences in the past few decades indicate that crop productivity growth in irrigated areas has slowed or stagnated and relying on irrigated agriculture for food security is not possible as data on water supply and demand are startling and as much as two-thirds of the world population could be water-stressed by 2025 (Seckler et al., 1999; Richter et al., 2003; Shah et al., 2006). In Indian scenario, in spite of spectacular increase in food grain production from 74 million tons during 1966-67 to 259 million tons during 2011-12, the country still struggles for ensuring food security of its people who have grown from 361 million in 1951 to 1210 million in 2011 and are expected to reach the levels of 1460 million by 2025 and 1700 million by 2050 (Government of India, 2014; FAOSTAT, 2017). Therefore, consistent efforts are needed to increase the current food production levels to more than 300 million tons by 2025 and around 380 million tons by 2050 (Amarasinghe et al., 2007). However, land resources are limited with almost no scope for expanding net sown area which has almost remained stagnant since the Green Revolution at about 141 million ha, but the cropping intensity has increased from about 1.17 in the late 1960 s/early 1970 s to 1.38 during 2011
(Government of India, 2014). Enhancing productivity is the way forward with limited opportunities in irrigated areas which are already near productivity plateau. The drylands with large yield gaps (Wani et al., 2012b), thus, occupy centre stage and currently cover majority $54 \%$ (76 million ha) of cultivable land and in spite of irrigation expansion programmes are projected to still cover $45 \%$ ( 63 million ha) of area by 2050 (Amarasinghe et al., 2007).

\subsubsection{Improved nutrient and water use efficiency}

Pilot studies (Chander et al., 2014) show that soil health building through balanced fertilization including micro- and secondary nutrient amendments not only increase productivity, but also improve $\mathrm{N}$ and most importantly $\mathrm{N}$ use efficiency. The results show improvements in uptake and use efficiency of $\mathrm{N}$ and thereby reducing pollution through losses in runoff water and as GHG emissions. Moreover, improvements in agricultural productivity, resulting in yield increase and denser foliage will involve a vapour shift from nonproductive evaporation in favour of productive transpiration. Various CSR pilot studies also corroborate the benefits of soil health building in effectively utilizing available water to get higher crop yields (Chander et al., 2013b, 2016).

\subsubsection{Soil C sequestration and offsetting GHG emissions}

Building soil health and managing $\mathrm{C}$ footprint is a great opportunity for CSR consortia to have a win-win proposition. Managing soil organic $\mathrm{C}$ is central because it influences numerous soil properties relevant to ecosystem functioning and crop growth. It is essential to improve soil resilience through beneficial impacts on the following processes (Lal, 2011):

- increase in soil aggregation and aggregate stability;

- improvement in total and macro-porosity;

- decrease in loss of soil water through increase in water infiltration rate and reduction in evaporation; 
- improvement in plant available water capacity;

- reduction in susceptibility to crusting, compaction and erosion by water and wind, and decrease in non-point source pollution of rivers and lakes;

- increase in soil's cation and anion exchange capacity;

- increase in plant nutrient reserves, both capacity and intensity factors;

- increase in microbial biomass $\mathrm{C}$, along with activity and species diversity of soil biota;

- increase in $\mathrm{CH}_{4}$ oxidation capacity, and moderation of rates of nitrification and denitrification;

- reduction in leaching losses of soluble plant nutrients;

- increase in soil's buffering capacity, and moderation of elemental balance; and

- improvement in agronomic production, through increase in use efficiency of energybased inputs (e.g. fertilizers, water and pesticides).

Even small changes in total $\mathrm{C}$ content can have disproportionately large impact on key soil physical properties (Powlson et al., 2011). An increase of 1 ton of soil $\mathrm{C}$ pool of degraded cropland soils may increase crop yield by $200-400$ $\mathrm{kg} / \mathrm{ha}$ of maize, $20-70 \mathrm{~kg} / \mathrm{ha}$ of wheat, $20-30$ $\mathrm{kg} / \mathrm{ha}$ of soybean, $5-10 \mathrm{~kg} / \mathrm{ha}$ of cowpea, 10 $50 \mathrm{~kg} / \mathrm{ha}$ of rice, $50-60 \mathrm{~kg} / \mathrm{ha}$ of millets and $20-30 \mathrm{~kg} / \mathrm{ha}$ of beans (Lal, 2011). Thus, an increase in the soil organic $\mathrm{C}$ pool within the root zone by 1 ton $C$ per ha per year can enhance food production in developing countries by $30-50$ million tons per year including 24-40 million tons per year of cereal and legumes, and 6-10 million tons per year of roots and tubers (Lal et al., 2007).

World soils play an important role in $\mathrm{C}$ cycling and represent the largest terrestrial pool of soil C of about $2500 \mathrm{pg} /$ billion ton $(1550 \mathrm{pg}$ soil organic $\mathrm{C}$ and $950 \mathrm{pg}$ soil inorganic $\mathrm{C}$ ) compared to about $700 \mathrm{pg}$ in the atmosphere and $600 \mathrm{pg}$ in land biota (Lal and Kimble, 1997; Batjes, 1999; Lal, 2004a,b). Most of the cultivated soils are depleted of soil organic $\mathrm{C}$ and far from saturation as is determined by climate, pedological and terrain characteristics (Lal, 2004a,b). The soils of different agroecosystems have lost their original soil organic pool with a global loss of
$78 \pm 12$ billion tons $\mathrm{C}$ through historic land misuse and soil degradation (Lal, 2011). Agriculture is important because of not only the potential to reduce its own emissions but also its potentiality to reduce net emissions from other sectors and to enhance the quality of soil, water and other natural resources and resilience-building (Lal, 2011). The global potential of $C$ sequestration in soils of agroecosystems is about 2.1 billion tons $\mathrm{C}$ per year and so if the soil organic $\mathrm{C}$ pool in world soils can be increased by $10 \%$ ( +250 billion tons) over the 21st century, it implies a drawdown of about $110 \mathrm{ppm}$ of atmospheric $\mathrm{CO}_{2}(1$ billion tons of soil C $=0.47 \mathrm{ppm}$ of atmospheric $\mathrm{CO}_{2}$ ).

Pilot studies prove that soil health building through balanced fertilization along with improved crop and water management can sequester $335 \mathrm{~kg} \mathrm{C}$ per ha per year (Wani et al., 2003). In degraded lands, biofuel plantations of Jatropha proved to have potential opportunities to rehabilitate degraded lands through adding to soil around $1450 \mathrm{~kg} \mathrm{C}$ per ha through leaf fall, pruned twigs, de-oiled cake along with $230 \mathrm{~kg} \mathrm{C}$ per ha replacement in fossil fuel and $5100 \mathrm{~kg} \mathrm{C}$ per ha as live plantation (Wani et al., 2012a).

\subsection{Framework for Soil Health and Ecosystem Services}

\subsubsection{Soil health building as an entry point activity}

Soil health mapping and building through needbased management addresses the widespread problem the farmers face and hence is one of the best entry point intervention for quick benefits and building rapport with the majority of farmers to initiate a collective action for technological upgradation of dryland agriculture (Wani $e t$ al., 2009a; Chander et al., 2016). The main attributes which make it the best entry point activity are: it is knowledge-based and does not involve direct cash payment; it has a high success probability (>80-90\%); involves participatory research and development approach; it results in the measurable tangible economic benefits to the farming community with a relatively high benefitcost ratio; is simple and easy for the participating farmers to undertake; involves participatory evaluation; has a reliable and cost-effective 
approach to assess the constraints; and most importantly it benefits the majority of farmers in the watershed.

\subsubsection{Strengthening analytical framework}

In a soil analysis process to start for building soil health, soil sampling is one of the most important and the weakest links. The smallest amount of sample collected must effectively represent the millions of $\mathrm{kg}$ soil in the field. Participatory stratified soil sampling method (Sahrawat et al., 2008) takes care of such errors. Under this method, the target region is divided into three topo-sequences. At each topo-sequence location, samples are taken proportionately from small, medium and large farm holdings to address the variations that may arise due to different management practices because of different economic status in each farm size class. Within each farm size class in a topo-sequence, the samples are chosen carefully to represent different soil colour, texture, cropping systems and agronomic management practices. At ultimate sampling unit in a farmer's field, 8-10 cores of surface (0-0.15 m) soil samples are collected and mixed together to make a composite sample.

Analysis is the next step followed and unless soil samples are thoroughly diagnosed for all essential elements and key parameters, holistic recommendations are unlikely to be developed. A fragmented approach of soil analysis is no longer workable. Precision is another important requirement as small errors in especially micronutrients may result in different interpretation and recommendations. Therefore, establishing stateof-the-art laboratories makes better sense technically as well as operationally as only one such laboratory can effectively cater to the requirements of a district. In current scenario, out of around 1600 laboratories ( 1500 static, $100 \mathrm{mo}-$ bile) in the country, only about 150 are equipped to analyse B and about 450 for $S$ and about 600 can analyse diethylene triamine pentaacetic acid (DTPA) extractable micronutrients ( $\mathrm{Zn}, \mathrm{Cu}$, $\mathrm{Fe}, \mathrm{Mn}$ ). Therefore, streamlining soil-plant-water diagnostic services through upgrading current half-functional laboratories into state-of-theart laboratories is better technically as well as operationally and one such laboratory per district could be a better proposition to improve operational efficiency and precision, rather than many half or non-functional laboratories (Wani et al., 2016).

The GIS (geographical information system) interpolation of analysis results across CSR and other pilot sites show that individual nutrient deficiencies are scattered differently across regions, and multiple nutrient deficiencies are also observed. In this scenario, current general practice of fertilizer recommendations at state or agroecoregion level does not effectively meet soil requirement and hence more precise recommendations at block/cluster-of-villages/village/ farmer level need to be developed and promoted.

The CSR pilot areas are sites of learning of using soil health building as an entry point activity, by using stratified soil sampling and promoting and evaluating block/village level soil test-based recommendations for soil health rejuvenation. The experience of International Crops Research Institute for the Semi-Arid Tropics (ICRISAT), Patancheru, Telangana in these pilots demonstrates the benefits of these and subsequently, as awareness develops amongst the farmers, and the government is geared up to handle knowledge dissemination especially for smallholders, farmer-based recommendations can be followed.

\subsubsection{Regulating soil $\mathrm{C}$ pools}

It is important to realize that low-input agricultural systems deplete soil organic $\mathrm{C}$ and accentuate the risk of greenhouse effects (Lal and Kimble, 1997). Long-term studies at ICRISAT (Wani et al., 2003) showed that improved system comprising landform management (broad-bed and furrow cultivation), soil test-based balanced fertilization and crop management increases not only crop productivity but also soil organic C content. In this historical study, an additional quantity of 7.3 tons $\mathrm{C}$ per ha $(335 \mathrm{~kg} \mathrm{C}$ per ha per year) was sequestered in soil under the improved system compared with the traditional system over the 24-year period (Table 3.4). The $\mathrm{C}$ inputs were found to increase with continuous cropping, particularly where fertilizers were applied and when legumes were included 
Table 3.4. Biological and chemical properties of semi-arid tropical Vertisols after 24 years of cropping under improved and traditional system at ICRISAT, Patancheru, India. From: Wani et al. (2003).

\begin{tabular}{llcc}
\hline & & \multicolumn{2}{c}{ Soil depth $(\mathrm{cm})$} \\
\cline { 3 - 4 } Properties & System & 0 to 60 & 60 to 120 \\
\hline Microbial biomass & Improved & 2676 & 2137 \\
$\mathrm{C}(\mathrm{kg} / \mathrm{ha})$ & Traditional & 1462 & 1088 \\
Organic C (tha) & Improved & 27.4 & 19.4 \\
& Traditional & 21.4 & 18.1 \\
Microbial biomass & Improved & 86.4 & 39.2 \\
$\mathrm{~N}(\mathrm{~kg} / \mathrm{ha})$ & Traditional & 42.1 & 25.8 \\
Total N (kg/ha) & Improved & 2684 & 1928 \\
& Traditional & 2276 & 1884 \\
Olsen-P (kg/ha) & Improved & 6.1 & 1.6 \\
& Traditional & 1.5 & 1.0 \\
\hline
\end{tabular}

in the system (Paustian et al., 1997; Wani et al., 2003). Leguminous plants are considered to have a competitive advantage under global climate change because of increased rates of symbiotic $\mathrm{N}$ fixation in response to increased atmospheric $\mathrm{CO}_{2}$ (Serraj, 2003; Wani et al,, 2003). Soil microbial biomass responds more rapidly than soil organic matter as a whole to changes in management that alter the annual input of organic material into soil C (Powlson and Jenkinson, 1981). Although small in mass, microbial biomass is one of the most labile pools of organic matter and thus serves as an important reservoir of plant nutrients such as $\mathrm{N}$ and $\mathrm{P}$ (Jenkinson and Ladd, 1981; Marumato et al., 1982). Biomass C, as a proportion of total soil C, serves as a surrogate for soil quality (Jenkinson and Ladd, 1981). In on-station study at ICRISAT (Wani et al., 2003), improved management practices of Vertisols resulted in higher values (10.3 vs $6.4 \%$ ) of biomass $\mathrm{C}$ as a proportion of soil organic C.

In a study on monitoring changes in soil $\mathrm{C}$ between 1980 and 2005 (Bhattacharyya et al., 2007), in two important food production zones of India, viz. the Indo-Gangetic Plains (IGP) (Punjab, Haryana, Uttar Pradesh, Bihar and West Bengal) and the black and associated red soils (BSR) (Andhra Pradesh, Madhya Pradesh, Karnataka, Gujarat and Maharashtra), soil organic $\mathrm{C}$ stock of both the soils was found to increase due to the turnover of more biomass to the soils (however, the increase was more in the IGP than the BSR). Thus, scaling-up improved management is needed as the soil organic C stocks of Indian soils demonstrate enough potential to sequester organic C (Pal et al., 2015). It is observed that vast areas of land in arid, semi-arid and drier part of sub-humid India are impoverished in soil organic C, but are high in soil inorganic $\mathrm{C}$ up to $30 \mathrm{~cm}$ depth. These specified areas are the prioritized ones for organic $\mathrm{C}$ management in soil. These areas cover 155.8 million ha of which, arid areas cover 4.9 , semi-arid 116.4 and dry sub-humid 34.5 million ha. Under different land use systems, soil organic $\mathrm{C}$ sequestration within the first $100 \mathrm{~cm}$ is observed to be higher in soils under forest, followed by horticultural and agricultural system (Pal et al., 2015).

To maintain soil organic matter status, there is need to add organic materials including manures, and crop residues on a regular basis to compensate the loss of organic matter by various processes. On-farm studies at ICRISAT (Chander et al., 2013a) have shown that the use of manures like vermicompost increased biomass production and apparently recycling and $\mathrm{C}$ sequestration, while cutting cost of chemical fertilizers and making it a profitable option for farmers to adopt. Recycling large quantities of $\mathrm{C}$ and nutrients contained in agricultural and domestic wastes ( $~ 700$ million tons organic wastes are generated annually in India) (Bhiday, 1994) are needed to rejuvenate soil health for enhancing productivity (Nagavallemma et al., 2006; Chander et al., 2013a; Wani et al., 2014)(Fig. 3.2). To start with, focus on agricultural regions, producing large quantities of residues which have little alternate uses, could be the best strategy. In this context, the hardy stems of crops like pigeonpea, cotton, maize, pearl millet, sorghum and others are best target biomass for recycling. These five crops are grown in around 37 million ha in India and produce more than 100 million $t$ hardy straw biomass per year which has little economic value or effective alternate use by farmers. This biomass is a potential opportunity to recycle plant nutrients worth more than Rs 3000 crores per year. For effective composting, these hardy residues need to be chopped into small pieces. Pilot studies in Andhra Pradesh have shown that arranging shredder machines on a sharing basis could be a good business 


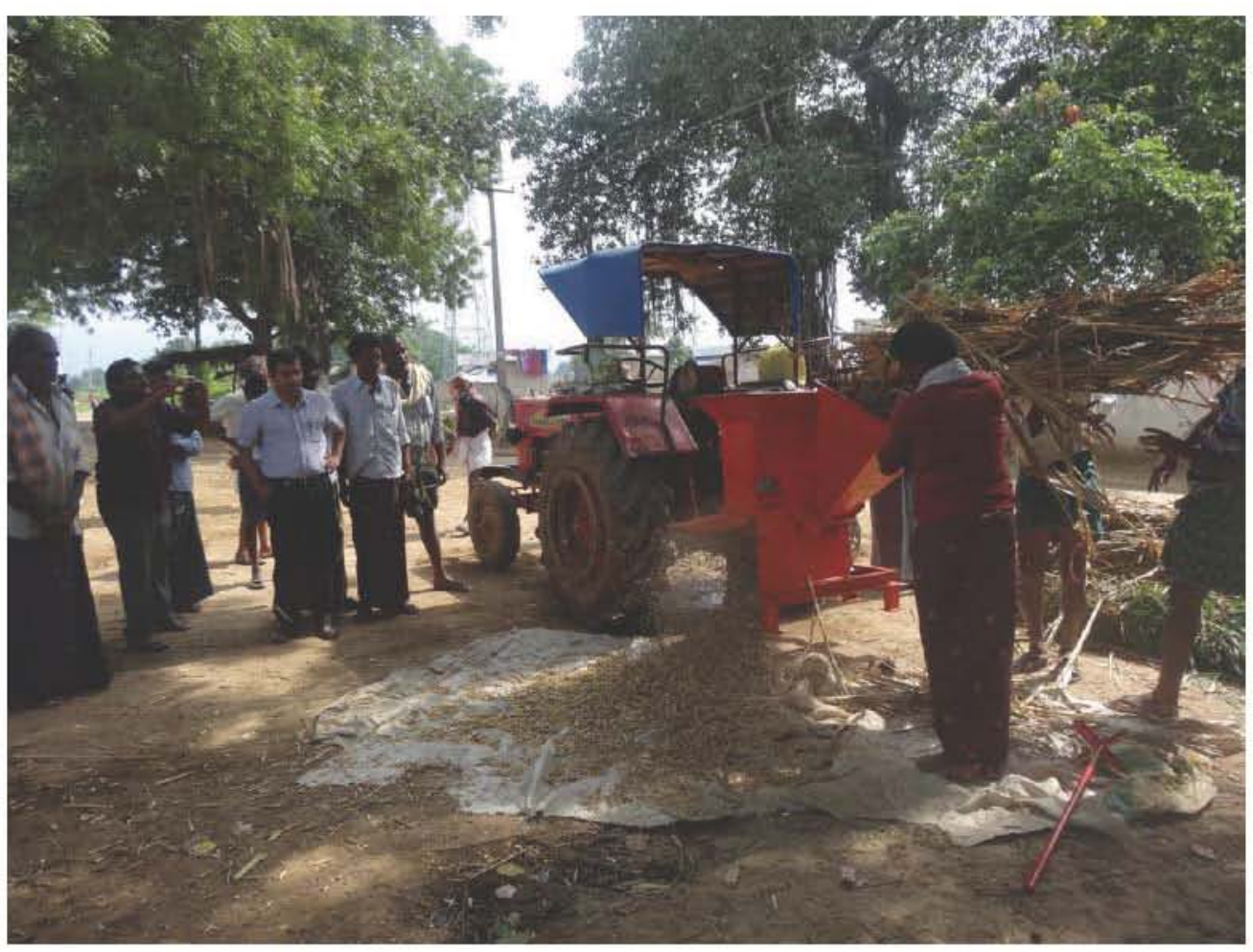

Fig. 3.2. Shredder machine piloted in Kadapa, Andhra Pradesh used to chop hardy biomass for composting.

model for chopping biomass for composting which prove to be economically remunerative from the first year. Alongside, composting technologies need to be scaled-out to farmers. Vermicomposting is a proven technology, but in many case desired success is not achieved due to the need for continuously maintaining moisture and arranging feeding material to earthworms. So, technologies like use of microbial consortium culture for composting needs to be promoted for undertaking it as and when needed and adding convenience to the farmers. Along with mapping for potential recyclable biomass in agriculture and horticulture, regions with current low chemical fertilizer use could also be prioritized and promoted as niche areas for organic farming without compromising with yield and harnessing premium price for the farmers. Also converting biomass into Biochar, having highly stable form of $\mathrm{C}$, may be a good option of building soil $\mathrm{C}$ for long term (Sohi et al., 2009); however, the long-term effects need to be evaluated.
Conservation agriculture (CA) may be a suitable technique for control of soil and $\mathrm{C}$ through erosion, lesser exposure for decomposition along with increased inputs of $\mathrm{C}$ as mulch. Some other studies indicate that crop rotations also play an important role in improvement in soil $\mathrm{C}$. However, the results in on-station experiment at ICRISAT showed no significant effect on maize, chickpea and pigeonpea yield with or without residue addition (Jat et al., 2012). Retained residues reduced total seasonal runoff under both the tillage practices (Jat $e t$ al., 2015). These results imply that under CA high rainwater filters into the soil to add to the green water. Similarly, peak rate of runoff, which indicates erosive capacity of runoff water is also decreased with residue addition. No significant benefit is observed of retaining residues in improving water use efficiency. The difficulty in sowing through surface retained residues and poor seed to soil contact under residue retained plots apparently led to lower plant stand and crop yield 
(Jat et al., 2015). The residue addition, though, tended to improve soil organic $\mathrm{C}$ levels.

In context of promoting biofuels for $\mathrm{Creplace-}$ ment in fossil fuels, on-farm research results (Wani et al., 2009b, 2012a; Wani and Chander, 2012) show plants like Jatropha (a hardy plant) to grow successfully and rejuvenate degraded lands without compromising on the food security in heavily populated countries like India which could help strengthen local livelihoods and income diversification. In wastelands planted with Jatropha, around $4000 \mathrm{~kg} / \mathrm{ha} /$ year organic matter (through leaf fall, pruned twigs and de-oiled cake) added not only $1450 \mathrm{~kg} \mathrm{C}$ per ha per year, but also $85.5 \mathrm{~kg} \mathrm{~N}, 7.67 \mathrm{~kg} \mathrm{P}, 43.9 \mathrm{~kg} \mathrm{~K}$, $5.20 \mathrm{~kg} \mathrm{~S}, 0.11 \mathrm{~kg} \mathrm{~B}$ and $0.12 \mathrm{~kg} \mathrm{Zn}$ per ha per year plus other essential nutrients (Wani et al., 2012a). Out of the total $\mathrm{C}$ accumulated by seeds, $185-230 \mathrm{~kg} \mathrm{C}$ per ha per year is as biodiesel/oil $\mathrm{C}$ and an apparent replacement in the fossil fuel. The live plant (shoot and root) biomass in the fields serves as a sink for $\mathrm{C}$ at $5120 \mathrm{~kg} \mathrm{C}$ per ha (Table 3.5). The soil samples from one on-farm plantation location (Velchal, Rangareddy district, Andhra Pradesh) recorded increased microbial biomass $\mathrm{C}$ by $22 \%$, soil respiration by $2.46 \%$ and microbial biomass $\mathrm{N}$ by $24 \%$ as compared to the adjoining grasslands (Wani et al., 2012a).

Management practices to reduce soil $\mathrm{C}$ loss by erosion is an important component as ecosystems in the semi-arid tropics are prone to land degradation, which may be aggravated by climate change. Soil erosion by water and loss of soil C and nutrients along with it is a major global

Table 3.5. Balance sheet of carbon (C) under Jatropha plantation as $C$ returned to soil, biodiesel $C$ replacement per year and live plant $C$. From: Wani et al. (2012a).

\begin{tabular}{llc}
\hline $\begin{array}{l}\text { C through } \\
\text { Jatropha } \\
\text { plantation }\end{array}$ & Plant part involved & $\begin{array}{c}\text { Organic C } \\
\text { (kg per ha) }\end{array}$ \\
\hline $\begin{array}{c}\text { C returned } \\
\text { back to soil }\end{array}$ & Leaf fall & $800^{\mathrm{a}}$ \\
& $\begin{array}{l}\text { Pruned twigs } \\
\text { De-oiled cake }\end{array}$ & $150^{\mathrm{a}}$ \\
$\begin{array}{c}\mathrm{C} \text { replacement } \\
\text { in fossil fuel }\end{array}$ & Jatropha oil & $235^{\mathrm{b}}$ \\
$\mathrm{C}$ in live plant & Shoots and roots & 5120 \\
\hline
\end{tabular}

'Leaf and pruned twigs added $\mathrm{C}$ every year. 'Jatropha oil C (fuel replacement) and de-oiled cake added $\mathrm{C}$ from fourth year onwards every year. environmental problem (Boardman and FavisMortlock, 2001). In climate change scenario, the frequency and intensity of extreme rainfall events are expected to increase in some regions, which could lead to increased erosion rates (Michael et al., 2005). In general, a 1\% change in precipitation is expected to result on average a $2.4 \%$ change in soil loss (Zhang et al., 2005). In context of impending climate change scenario, development of the watershed/catchment is one of the most trusted and ecofriendly approaches to managing natural resources and reducing runoff, soil loss and C therein (Wani et al., 2012b). Desilting water tanks and application of tank sediment to agricultural fields (which are integral part of villages especially in India) is also an economically feasible (benefit-cost ratio of 1.23) option to return organic $\mathrm{C}$ and nutrients (Padmaja et al., 2003). The sediment samples in Medak district, Telangana contained $720 \mathrm{mg} \mathrm{N}$, $320 \mathrm{mg} \mathrm{P}$ and $10.7 \mathrm{~g} \mathrm{C}$ per kg of sediment. During 2001, under Government of Andhra Pradesh initiative, namely 'Neeru-Meeru', 246,831 tons of sediment desilted and added to the farms returned 183 tons $\mathrm{N}, 86$ tons $\mathrm{P}$ and 2873 tons of organic C.

\subsubsection{GHG emissions and management}

Global warming induced climate change caused by $\mathrm{CO}_{2}$ (and other $\mathrm{GHGs}$ ) emissions through fossil fuel combustion (IPCC, 2007) is an issue of concern worldwide. The $\mathrm{CO}_{2}$ concentration has increased markedly in the 21 st century at a rate of $2 \mathrm{ppm}$ (parts per million) per year during 2000 onwards. The $\mathrm{CO}_{2}$ concentration was 280 $\mathrm{ppm}$ in the pre-industrial times, and has crossed 400 ppm (Fig. 3.3). Atmospheric $\mathrm{CO}_{2}$ levels are increasing at a rate of $0.4 \%$ per year and are predicted to double by 2100 (Lal, 2005; IPCC, 2007). The Intergovernmental Panel on Climate Change has shown that the earth temperature has increased by $0.74^{\circ} \mathrm{C}$ between 1906 and 2005 due to the increase in anthropogenic emissions of GHGs (Aggarwal, 2008). Global temperatures are predicted to increase by 1.1 to $6.4^{\circ} \mathrm{C}$ between 1990 and 2100 depending on $\mathrm{CO}_{2}$ emission scenarios, with $\mathrm{CO}_{2}$ atmospheric concentration projected to increase in the range 550 to $850 \mathrm{ppm}$ (Stockle et al., 2011). These 


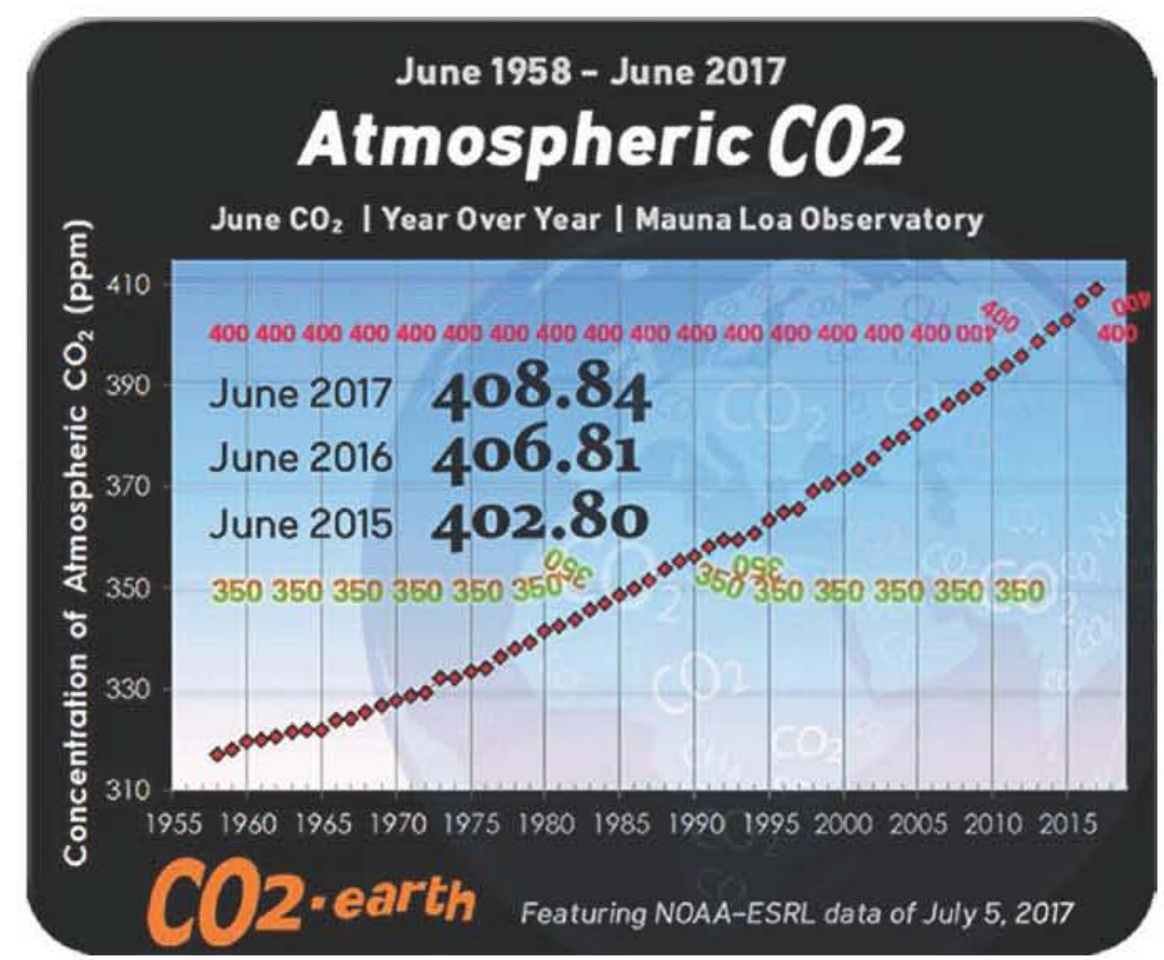

Fig. 3.3. Atmospheric $\mathrm{CO}_{2}$ levels measured at Mauna Loa Observatory, Hawaii (NOAA-ESRL), 2017. From: Mauna Loa Observatory, 2017.

changes will have a profound impact on the natural resource base that agriculture depends upon. It is likely that climate variability and change will exacerbate food insecurity in areas currently vulnerable to hunger and undernutrition. Climate change is now being viewed as the single gravest threat to food security worldwide. There is a strong link between food insecurity, soil degradation and climate change, yet the twin crisis of climate change and food insecurity may be significantly addressed through restoration of soil organic $\mathrm{C}$.

Current global GHG emissions (in terms of $\mathrm{CO}_{2}$ equivalents $\left.\left(\mathrm{CO}_{2} \mathrm{e}\right)\right)$ are about $49 \mathrm{Gt} \mathrm{CO}_{2} \mathrm{e} /$ year, $74 \%$ of which are $\mathrm{CO}_{2}, 16 \%$ of $\mathrm{CH}_{4}$ and $10 \%$ of $\mathrm{N}_{2} \mathrm{O}$. Agriculture accounts for around $13.5 \%$ of the total global anthropogenic GHG emissions, contributing about $25 \%, 50 \%$ and $70 \%$ of $\mathrm{CO}_{2}, \mathrm{CH}_{4}$ and $\mathrm{N}_{2} \mathrm{O}$ respectively (Montzka et al., 2011). As food crops production needs to be increased at a rate not less than $1.3 \%$ annually (Cassman et al., 2003), GHG emissions are also expected to increase, if adequate measures to minimize the emissions are not taken. The GHG emissions from agriculture in the form of $\mathrm{N}_{2} \mathrm{O}$ emit from fertilizer management practices. Agricultural activities add into the atmosphere about 4.2 to $7 \mathrm{Tg} \mathrm{N}$ annually in the form of $\mathrm{N}_{2} \mathrm{O}$ (Del Grosso et al., 2008). Nitrous oxide has high global warming potential of 298-fold. Increased soil temperatures coupled with high moisture conditions during cooler months will increase $\mathrm{N}_{2} \mathrm{O}$ production in soil. Elevation in $\mathrm{CO}_{2}$ concentrations is also projected to increase $\mathrm{N}_{2} \mathrm{O}$ emissions from upland agricultural soils (Van Groeningen et al., 2011). Regarding $\mathrm{CO}_{2}$, soil respiration is an important source, but the majority of the farm operations and inputs, such as fertilizers, pesticides and energy, also have embodied $\mathrm{CO}_{2}$ content. Rice cultivation is a major source of $\mathrm{CH}_{4}$, currently accounting for $10-15 \%$ of all global GHG emissions from agriculture and 10-12\% of the world's total anthropogenic $\mathrm{CH}_{4}$ emissions (IPCC, 2014).

In agriculture, increasing soil $\mathrm{C}$ represents the greatest mitigation potential. About 50-66\% 
of the cumulative historic $\mathrm{C}$ loss from soil can be recovered through proper management (Lal, 2004a). Increasing soil organic $C$ content in soil may lock the $\mathrm{C}$ out of the atmosphere for centuries by $\mathrm{C}$ sequestration. Managing agricultural land to increase soil $\mathrm{C}$ has a mitigation potential of 5340 million tons $\mathrm{CO}_{2} \mathrm{e} /$ year. Much of this mitigation effort has an economic cost and this technical potential equates to an economic potential of 4300 million tons $\mathrm{CO}_{2} \mathrm{e} /$ year at $\mathrm{C}$ price of US\$100 per ton $\mathrm{CO}_{2} \mathrm{e}$ (Murphy-Bokern and Kleemann, 2014). About $89 \%$ of this mitigation potential lies in soil $\mathrm{C}$ sequestration, and the remaining $11 \%$ arises from reducing emissions of methane $(9 \%)$ and $\mathrm{N}_{2} \mathrm{O}(2 \%)$. Identification and adoption of better management practices as discussed in the chapter can be used as a GHG offsetting tool. In rice cultivation, zero tillage reduces $\mathrm{CH}_{4}$ and $\mathrm{N}_{2} \mathrm{O}$ emissions, but increases $\mathrm{CO}_{2}$ emissions (Pandey et al., 2012; Ladha et al., 2016). Tillage, moisture and aeration, and $C$ supply affect $\mathrm{CH}_{4}$ emissions (Wassmann et al., 2000; Venterea et al., 2005). The management practices such as alternate wetting and drying, alternative rice land preparation and crop establishment were reported to cause lower methane emissions from rice paddies (Adhya et al., 2014; Linquist et al., 2015; Ladha et al., 2016). In areas where cropping system diversification is feasible, there is also scope for mitigation of GHG emissions in the rice-based ecosystem, while enhancing crop production (Ladha et al., 2016). Improved agronomic practices, increased $\mathrm{N}$ use efficiency, use of diversified cropping systems, adoption of crop cultivars with high harvest index, and the use of soil bioresources such as P-solubilizers and arbuscular mycorrhizal fungi in crop production were reported to lower the average $\mathrm{C}$ footprint in semi-arid areas (Gan et al., 2011). The over-exploitation of groundwater by agriculture for irrigation during recent years has lowered aquifer levels in many Asian countries, and pumping water from lower strata in the future would result in a greater use of energy, which is mostly generated by coal combustion, and would therefore result in increased emissions of GHG (Zhang et al., 2013). Improved water use efficiency is likely to become a critical criterion for many grain-producing areas in South Asia, in part due to necessary adaptation to the anticipated adverse effects from climate change (Elliott et al., 2014). Land use change and emission reduction in agriculture will be key elements in achieving an $80 \%$ reduction in GHG emissions by 2050 (Rockström et al., 2013).

The industry, with its high level of emissions, waste generation and fossil fuel consumption, is the major contributor to GHG emissions and climate change. However, industries in India are determined to become responsible corporations by undertaking CSR programmes. Data of the Ministry of Corporate Affairs on CSR expenditure of Indian companies in 2014-15 showed that $14 \%$ (₹ 1,213 crore) of total CSR expenses in India was made on activities focusing on conserving the environment. Carbon Disclosure Project survey conducted in UK by Doda et al. (2016) revealed little evidence that commonly adopted management practices by industry are reducing emissions. However, Murphy-Bokern and Kleemann (2014) felt that considering the commercial constraints and the obligations of firms to shareholders, CSR is contributing to climate protection. Corporates need to invest more in agricultural research and extension and should play a key role in enabling farmers to produce more food with minimal GHG emissions.

\subsubsection{Scaling-out soil health management}

Bhoochetana scaling-up initiative, with the support of Government of Karnataka and ICRISAT-led consortium as a technical partner, is an exemplary initiative of rejuvenating degraded farm lands and C-building which have shown significant productivity benefits. With this initiative in Karnataka state during 2009 to 2013, more than 5 million farmers benefited and net economic benefits through increased production were estimated at $\sim$ US\$353 million (₹1963 crore) (Wani et al., 2017).

Taking the lead from Bhoochetana, the government-supported Rythu Kosam initiative in Andhra Pradesh is unique in targeting system productivity through embracing allied sectors along with focus on core agricultural crops (i.e. Primary Sector). The Department of Agriculture, Government of Andhra Pradesh along with ICRISAT as a technical partner have used scalingout soil health building to harness benefits due to these interventions having high levels of success 
in more than 2 million ha during 2015 and 2016, and pilot-tested innovative $\mathrm{C}$-building technologies using microbial consortia cultures. Soil health building initiatives have monetary benefits through higher productivity in agricultural and horticultural crops to the tune of around ₹ 1100 crore.

Lessons learnt in such initiatives in Karnataka and Andhra Pradesh states in India indicated that improving food security and livelihoods of people need not wait for any new major scientific breakthrough, but a political will, collective action and innovations in technologies to reach farmers' doorsteps and soil health building and improving $\mathrm{C}$ footprints is the most effective entry point activity to harness benefits.

\subsubsection{Innovative extension and information and communication technology in soil health management}

Innovative extension ways for information dissemination have been explored during watershed projects and other productivity improvement programmes to improve the awareness and adoption rate among the farmers. In the context of soil health management, the key information dissemination tools were soil health cards, wall writings and android-based mobile App. Soil health cards are customized information cards of soil fertility status and crop-wise fertilizer recommendation. This is one of the entry point activities, which built good relationship with the community. The soil health card has information about the farmer, location information of the farm, status of major and micronutrients, and crop-wise fertilizer recommendation for the major crops based on fertility status. The soil health card programme is also widely adopted by Government of India for doubling the farmers' income.

Information related to soil fertility status has been also disseminated among the farmers through writing the information on the walls of common infrastructure in villages. This tool provides wider dissemination channel as all people from the village get access to this information. This tool has been also used in a watershed project for disseminating weather information and project details. Information written on the wall will be available for all the farmers from villages. However, this information is not customized like the crops or landholding. Soil health cards may provide customized fertilizer management solution, but that information is too static in nature. Thus, a dynamic information dissemination and monitoring tool is required to strengthen the local extension agent by providing a channel for information flow and to monitor the real time agriculture status on ground. In this context, the digital technologies with three important tools were piloted in Bhoochetana programme: Krishi Gyan Sagar, Krishi Vani and farmer-to-farmer video dissemination (Wani et al., 2017).

A mobile App is another potential opportunity in soil health management and key features of this are the soil fertility maps and soil test-based fertilizer management (Fig. 3.4). Geospatial digital maps were prepared based on the results from state-wide soil samples. The same soil analysis data was adopted in mobile app in two forms: (i) district level soil fertility maps including status of organic C, P, K, S, B and Zn are embedded in the app; and (ii) site-specific fertilizer recommendation for the major crops. Thus, with the power of a geospatial database of soil fertility, this application provides dynamic customization that is not possible with soil health cards or information written on walls.

\subsection{Summary and Key Findings}

- Rejuvenating soil health is needed for food and nutritional security of the rising population, while contributing to improving $\mathrm{C}$ footprints through $\mathrm{C}$ sequestration and minimizing GHGs.

- A holistic soil health mapping and needsbased management that encompasses stratified sampling, quality analysis and timely availability of required inputs along with desired policy support are needed.

- Desired policies to promote quality organic manures by recycling organic wastes generated both in urban and rural areas along with biofertilizers are desired.

- For sustainability, land use planning based on land and agroecological capability is needed through policy.

- Pilot sites need to be established as exemplary sites for training as well as developmental purposes. 


\begin{tabular}{|c|c|}
\hline 可可 & alle 14:51 \\
\hline KGS & (9) $\therefore 83$ \\
\hline Soil Maps-Chikmagalur & 2 \\
\hline
\end{tabular}

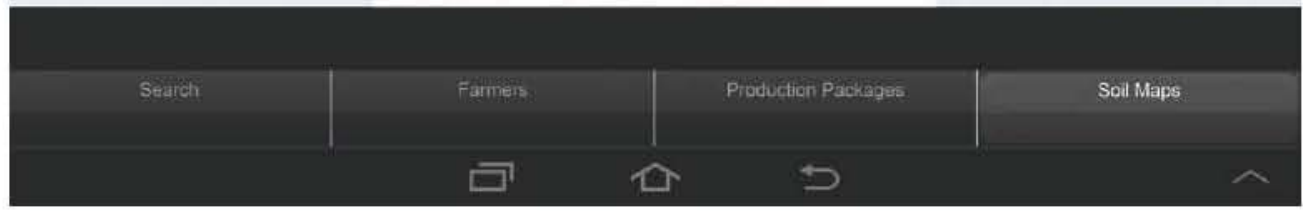

Fig. 3.4. District-wise soil fertility maps in Krishi Gyan Sagar App.

- There is an urgent need to reform the knowledge delivery systems by using innovative partnerships, tools, approaches and methods. Information and communication technologybased knowledge dissemination, etc. need to be developed.

- To address multifarious issues in soil health building and improving $\mathrm{C}$ footprints, a range of actors need to act together in a consortium model to harness their strengths and synergies with the local community as the primary implementing unit.
- Public-private partnerships are required as the governance strategy to minimize the transaction costs and coordinating and enforcing relations between the partners engaged in production of goods and services.

\section{Acknowledgement}

The authors duly acknowledge CSR partners for supporting soil health and C-building initiatives across the pilots.

\section{References}

Adhya, T.K., Linquist, B., Searchinger, T., Wassmann, R. and Yan, X. (2014) Wetting and Drying: Reducing Greenhouse Gas Emissions and Saving Water from Rice Production. Working paper, Installment 8 of Creating a Sustainable Food Future. World Resources Institute, Washington, DC.

Aggarwal, P.K. (2008) Global climate change and Indian agriculture: impacts, adaptation and mitigation. Indian Journal of Agricultural Sciences 78(11), 911-919.

Amarasinghe, U.A., Shah, T., Turral, H. and Anand, B.K. (2007) India's Water Future to 2025-2050: Business As-usual Scenario and Deviations. IWMI Research Report 123. International Water Management Institute, Colombo, Sri Lanka.

Batjes, N.H. (1999) Management Options for Reducing $\mathrm{CO}_{2}$ Concentrations in the Atmosphere by Increasing Carbon Sequestration in the Soil. International Soil Reference and Information Centre, Wageningen, the Netherlands.

Bhattacharyya, T., Chandran, P., Ray, S.K., Pal, D.K., Venugopalan, M.V. et al. (2007) Changes in levels of carbon in soils over years of two important food production zones of India. Current Science 93(12), 1854-1863. 
Bhiday, M.R. (1994) Earthworms in agriculture. Indian Farming 43(12), 31-34.

Blümmel, M., Samad, M., Singh, O.P. and Amede, T. (2009) Opportunities and limitations of food-feed crops for livestock feeding and implications for livestock-water productivity. Rangeland Journal 31, 207-213.

Boardman, J. and Favis-Mortlock, D.T. (2001) How will future climate change and land-use change affect rates of erosion on agricultural land? In: Ascough, J.C. and Flanagan, D.C. (eds) Soil Erosion Research for the 21st Century. Proceedings of the International Symposium, 3-5 January 2001, HonoIulu, Hawaii, USA. ASAE, St Joseph, MI, pp. 498-501.

Cassman, K.G., Dobermann, A., Walters, D.T. and Yang, H. (2003) Meeting cereal demand while protecting natural resources and improving environmental quality. Annual Review of Environment and Resources 28, 315-358.

Chander, G., Wani, S.P., Sahrawat, K.L., Kamdi, P.J., Pal, C.K. et al. (2013a) Balanced and integrated nutrient management for enhanced and economic food production: case study from rainfed semi-arid tropics in India. Archives of Agronomy and Soil Science 59(12), 1643-1658.

Chander, G., Wani, S.P., Sahrawat, K.L., Pal, C.K. and Mathur, T.P. (2013b) Integrated plant genetic and balanced nutrient management enhances crop and water productivity of rainfed production systems in Rajasthan, India. Communications in Soil Science and Plant Analysis 44, 3456-3464.

Chander, G., Wani, S.P., Sahrawat, K.L. and Rajesh, C. (2014) Enhanced nutrient and rainwater use efficiency in maize and soybean with secondary and micro nutrient amendments in the rainfed semi-arid tropics. Archives of Agronomy and Soil Science 61(3), 285-298.

Chander, G., Wani, S.P., Krishnappa, K., Sahrawat, K.L., Pardhasaradhi, G. and Jangawad, L.S. (2016) Soil mapping and variety based entry-point interventions for strengthening agriculture-based livelihoods exemplar case of 'Bhoochetana' in India. Current Science 110(9), 1683-1691.

Dagar, J.C. (2005) Salinity research in India: an overview. Bulletin of the National Institute of Ecology 15, 69-80.

Del Grosso, S.J., Wirt, T., Ogle, S.M. and Parton, W.J. (2008) Estimating agricultural nitrous oxide emissions. Eos Transactions of the American Geophysical Union 89, 529-530.

Doda, B., Gennaioli, C., Gouldson, A., Grover, D. and Sullivan, R. (2016) Are corporate carbon management practices reducing corporate carbon emissions? Corporate Social Responsibility and Environmental Management 23(5), 257-270.

Elliott, J., Deryng, D., Müller, C., Frieler, K., Konzmann, M. et al. (2014) Constraints and potentials of future irrigation water availability on agricultural production under climate change. Proceedings of the $\mathrm{Na}$ tional Academy of Science 111, 3239-3244.

FAO and ITPS (2015) Status of the World's Soil Resources (SWSR) - Main Report. Food and Agriculture Organization of the United Nations and Intergovernmental Technical Panel on Soils, Rome.

FAOSTAT (2017) Annual population data. Available at: http://faostat.fao.org/site/550/default.aspx\#ancor (accessed 9 April 2018).

Gan, Y., Liang, C., Hamel, C., Cutforth, H. and Wang, H. (2011) Strategies for reducing the carbon footprint of field crops for semiarid areas. A review. Agronomy for Sustainable Development 31, 643-656.

Government of India (2014) Agricultural Statistics at a Glance 2014. Directorate of Economics and Statistics, Ministry of Agriculture, New Delhi.

Haileslassie, A., Blümmel, M., Clement, F., Descheemaeker, K., Amede, T. et al. (2011) Assessment of livestock feed and water nexus across mixed crop livestock system's intensification gradient: an example from the Indo-Ganga Basin. Experimental Agriculture 47, 113-132.

Haileslassie, A., Blümmel, M., Wani, S.P., Sahrawat, K.L., Pardhasaradhi, G. and Anandan Samireddypalle (2013) Extractable soil nutrient effects on feed quality traits of crop residues in the semiarid rainfed mixed crop-livestock farming systems of Southern India. Environment, Development and Sustainability $15,723-741$.

IPCC (2007) Climate Change 2007: Synthesis Report. Intergovernmental Panel on Climate Change. Available at: https:/www.ipcc.ch/pdf/assessment-report/ar4/syr/ar4_syr_full_report.pdf (accessed 9 April 2018).

IPCC (2014) Climate Change 2014: Mitigation of Climate Change. Contribution of Working Group III to the Fifth Assessment Report of the Intergovernmental Panel on Climate Change. Cambridge University Press, Cambridge.

Jat, R.A., Wani, S.P., Piara Singh, Pathak, P., Srinivas, K. et al. (2012) Effect of conservation agriculture on productivity and economics of different cropping systems under rainfed conditions in the semi-arid tropics. In: Extended Summaries Vol. 3, 3rd International Agronomy Congress, Nov 26-30, 2012, New Delhi. Indian Society of Agronomy, New Delhi, pp. 888-890. 
Jat, R.A., Pathak, P., Wani, S.P., Piara Singh, Chander, G. and Sudi, R.S. (2015) Evaluating climate change mitigation and adaptation potential of conservation agriculture in semi-arid tropics of Southern India. British Journal of Environment \& Climate Change 5(4), 324-338.

Jenkinson, D.S. and Ladd, J.N. (1981) Microbial biomass in soil: measurement and turnover. In: Paul, E.A. and Ladd, J.N. (eds) Soil Biochemistry, Vol. 5. Dekker, New York, pp. 415-471.

Ladha, J.K., Rao, A.N., Raman, A., Padre, A., Dobermann, A. et al. (2016) Agronomic improvements can make future cereal systems in South Asia far more productive and result in a lower environmental footprint. Global Change Biology 22, 1054-1074.

Lal, R. (2004a) Soil carbon sequestration impacts on global climate change and food security. Science (Washington) 304, 1623-1627.

Lal, R. (2004b) Carbon emission from farm operations. Environment International 30, 981-990.

Lal, R. (2005) Forest soils and carbon sequestration. Forest Ecology and Management 220, 242-258.

Lal, R. (2011) Sequestring carbon in soils of agro-ecosystems. Food Policy 36, S33-S39.

Lal, R. and Kimble, J.M. (1997) Conservation tillage for carbon sequestration. Nutrient Cycling in Agroecosystems 49, 243-253.

Lal, R., Follett, R.F., Stewart, B.A. and Kimble, J.M. (2007) Soil carbon sequestration to mitigate climate change and advance food security. Soil Science 172(12), 943-956.

Linquist, B.A., Anders, M.M., Adviento-Borbe, M.A.A., Chaney, R.L., Nalley, L.L. et al. (2015) Reducing greenhouse gas emissions, water use, and grain arsenic levels in rice systems. Global Change Biology 21, 407-417.

Marumato, T., Anderson, J.P.E. and Domsch, K.H. (1982) Mineralisation of nutrients from soil microbial biomass. Soil Biology and Biochemistry 14, 469-475.

Mauna Loa Observatory (2017) Atmospheric $\mathrm{CO}_{2}$. Available at: https://www.co2.earth (accessed 9 April 2018).

Michael, A., Schmidt, J., Enke, W., Deutschländer, T. and Malitz, G. (2005) Impact of expected increase in precipitation intensities on soil loss - results of comparative model simulations. Catena 61(2/3), 155-164.

Montzka, S.A., Dlugokencky, E.J. and Butler, J.H. (2011) Non- $\mathrm{CO}_{2}$ greenhouse gases and climate change. Nature 476, 46-50.

Munir, A., Hanjra, M. and Qureshi, E.M. (2010) Global water crisis and future food security in an era of climate change. Food Policy $35,365-377$.

Murphy-Bokern, D. and Kleemann L. (2014) The Role of Corporate Social Responsibility in Reducing Greenhouse Gas Emissions from Agriculture and Food. Draft for public consultation. A study for the International Food Policy Research Institute. Available at: http://www.murphy-bokern.com/images/ IFPRI_CR_Report_July_2015.pdf (accessed 9 April 2018).

Nagavallemma, K.P., Wani, S.P., Lacroix, S., Padmaja, V.V., Vineela, C. et al. (2006) Vermicomposting: recycling wastes into valuable organic fertilizer. SAT eJournal 2(1), 1-16.

National Bureau of Soil Survey and Land Use Planning (NBSS \& LUP). (2005) Annual Report 2005. Nagpur, India: NBSS \& LUP.

Nkonya, E.M., Mirzabaev, A. and von Braun, J. (2016) Economics of Land Degradation and Improvement - A Global Assessment for Sustainable Development. Springer International Publishing, Cham, Switzerland.

Padmaja, K.V., Wani, S.P., Lav Aggarval and Sahrawat, K.L. (2003) Economic Assessment of Desilted Sediment in Terms of Plant Nutrients Equivalent: A Case Study in the Medak District of Andhra Pradesh. Global Theme 3: Water, Soil and Agrodiversity Management for Ecosystem Resilience Report no. 4. International Crops Research Institute for the Semi-Arid Tropics, Patancheru, India.

Pal, D.K., Wani, S.P. and Sahrawat, K.L. (2015) Carbon sequestration in Indian soils: present status and the potential. Proceedings of the National Academy of Science, India, Section B, Biological Sciences 85(2), 337-358.

Pandey, D., Agrawal, M. and Bohra, J.S. (2012) Greenhouse gas emissions from rice crop with different tillage permutations in rice-wheat system. Agriculture, Ecosystems \& Environment 159, 133-144.

Paustian, K., Colins, H.P. and Paul, E.A. (1997) Management controls on soil carbon. In: Paul, E.A., Paustian, K., Elliott, E.T. and Cole, C.V. (eds) Soil Organic Matter in Temperate Agro-Ecosystems: Long-Term Experiments in North America. CRC Press, Boca Raton, FL, pp. 15-49.

Paustian, K., Cole, C.V., Sauerbeck, D. and Sampson, N. (1998) $\mathrm{CO}_{2}$ mitigation by agriculture: an overview. Climatic Change 40, 135-162.

Powlson, D.S. and Jenkinson, D.S. (1981) A comparison of the organic matter, biomass, adenosine triphosphate and mineralizable nitrogen contents of ploughed and direct drilled soils. The Journal of Agricultural Science (Cambridge) 97, 713-721. 
Powlson, D.S., Gregory, P.J., Whalley, W.R., Quinton, J.N., Hopkins, D.W. et al. (2011) Soil management in relation to sustainable agriculture and ecosystem services. Food Policy 36(1), 72-87.

Richter, B.D., Mathews, R., Harrison, D.L. and Wigington, R. (2003) Ecologically sustainable water management: managing river flows for ecological integrity. Ecological Applications 13, 206-224.

Rockstrōm, J., Sachs, J.D., Ohman, M.C. and Schmidt-Traub, G. (2013) Sustainable Development and Planetary Boundaries. Thematic group on agro-economics, population dynamics, and planetary boundaries. Background research paper prepared by the co-chairs of the Sustainable Development Solutions Network. High Level Panel on the Post-2015 Development Agenda, United Nations. Available at: http://www.post2015hlp.org/wp-content/uploads/2013/06/Rockstroem-Sachs-Oehman-SchmidtTraub_Sustainable-Development-and-Planetary-Boundaries.pdf (accessed 9 April 2018).

Sahrawat, K.L., Rego, T.J., Wani, S.P. and Pardhasaradhi G. (2008) Stretching soil sampling to watershed: evaluation of soil-test parameters in a semi-arid tropical watershed. Communications in Soil Science and Plant Analysis 39, 2950-2960.

Sahrawat, K.L., Wani, S.P. and Pardhasaradhi, G. (2013) Balanced nutrient management: effects on plant zinc. Journal of SAT Agricultural Research 11, 1-3.

Scherr, S.J. and Yadav, S. (1996) Land Degradation in the Developing World: Implications for Food, Agriculture, and the Environment to 2020. Food, Agriculture, and the Environment Discussion Paper 14. International Food Policy Research Institute, Washington, DC.

Seckler, D., Barker, R. and Amarasinghe, U. (1999) Water scarcity in the twenty-first century. International Journal of Water Resources Development 15(1/2), $29-42$.

Serraj, R. (2003) Atmospheric $\mathrm{CO}_{2}$ increase benefits symbiotic $\mathrm{N}_{2}$ fixation by legumes under drought. Current Science 85(9), 1341-1343.

Shah, T., Singh, O.P. and Mukherji, A. (2006) Some aspects of South Asia's groundwater irrigation economy: analyses from a survey in India, Pakistan, Nepal Terai and Bangladesh. Hydrogeology Journal 14(3), 286-309.

Sohi, S., Lopez-Capel, E., Krull, E. and Bol, R. (2009) Biochar, Climate Change and Soil: A Review to Guide Future Research. CSIRO Land and Water Science Report. Commonwealth Scientific and Industrial Research Organisation, Canberra, Australia.

Stockle, C.O., Marsal, J. and Villar, J.M. (2011) Impact of climate change on irrigated tree fruit production. Acta Horticulturae 889, 41-52.

UN (2016) World Population Prospects, the 2015 Revision. Department of Economic and Social Affairs, Population Division, New York.

UN (2017) Sustainable Development Goals - 17 Goals to Transform Our World. United Nations, New York. Available at: http://www.un.org/sustainabledevelopment/sustainable-development-goals (accessed 4 April 2017).

Uppal, R.K., Wani, S.P., Garg, K.K. and Alagarswamy, G. (2015) Balanced nutrition increases yield of pearl millet under drought. Field Crops Research 177, 86-97.

Van Groeningen, K.J., Osenberg, C.W. and Hungate, B.A. (2011) Increased soil emissions of potent greenhouse gases under increased atmospheric $\mathrm{CO}_{2}$. Nature 475, 214-216.

Venterea, R.T., Burger, M. and Spoka, K.T. (2005) Nitrogen oxide and methane emissions under varying tillage and fertilizer management. Journal of Environmental Quality 34, 1467-1477.

Wani, S.P. and Chander, G. (2012) Jatropha curcas biodiesel - is it a panacea for energy crisis, ecosystem service and rural livelihoods? Challenges and opportunities. In: Bahadur, B., Sujatha, M. and Carels, N. (eds) Jatropha - Challenges for a New Energy Crop. Springer Science, New York, pp. 311-331.

Wani, S.P. and Chander, G. (2016) Role of micro and secondary nutrients in achieving food and nutritional security. Advances in Plants \& Agriculture Research 4(2), 131.

Wani, S.P., Pathak, P., Jangawad, L.S., Eswaran, H. and Singh, P. (2003) Improved management of Vertisols in the semi-arid tropics for increased productivity and soil carbon sequestration. Soil Use and Management 19(3), 217-222.

Wani, S.P., Sahrawat, K.L., Sreedevi, T.K., Pardhasaradhi, G. and Dixit, S. (2009a) Knowledge-based entry point for enhancing community participation in integrated watershed management. In: Best-bet Options for Integrated Watershed Management - Proceedings of the Comprehensive Assessment of Watershed Programs in India, 25-27 July 2007. International Crops Research Institute for the Semi-Arid Tropics, Patancheru, India, pp. 53-68.

Wani, S.P., Sreedevi, T.K., Marimuthu, S., Kesava Rao, A.V.R. and Vineela, C. (2009b) Harnessing the potential of Jatropha and Pongamia plantations for improving livelihoods and rehabilitating degraded 
lands. In: 6th International Biofuels Conference, 4-5 March 2009, New Delhi. Winrock International India, New Delhi.

Wani, S.P., Chander, G., Sahrawat, K.L., Srinivasa Rao Ch., Raghvendra, G., Susanna, P. and Pavani, M. (2012a) Carbon sequestration and land rehabilitation through Jatropha curcus (L.) plantation in degraded lands. Agriculture, Ecosystems \& Environment 161, 112-120.

Wani, S.P. Dixin, Y., Li, Z., Dar, W.D. and Chander, G. (2012b) Enhancing agricultural productivity and rural incomes through sustainable use of natural resources in the SAT. Journal of the Science of Food and Agriculture 92, 1054-1063.

Wani, S.P., Chander, G. and Vineela, C. (2014) Vermicomposting: recycling wastes into valuable manure for sustained crop intensification in the semi-arid tropics. In: Chandra, R. and Raverkar, K.P. (eds) Bioresources for Sustainable Plant Nutrient Management. Satish Serial Publishing House, Delhi, pp. 123-151.

Wani, S.P., Chander, G., Sahrawat, K.L. and Pardhasaradhi, G. (2015) Soil test-based balanced nutrient management for sustainable intensification and food security: case from Indian semi-arid tropics. Communications in Soil Science and Plant Analysis 46(S1), 20-33.

Wani, S.P., Chander, G., Bhattacharyya, T. and Patil, M. (2016) Soil Health Mapping and Direct Benefit Transfer of Fertilizer Subsidy. Research Report IDC-6. International Crops Research Institute for the Semi-Arid Tropics, Patancheru, India. Available at: http://oar.icrisat.org/9747/1/2016-088\%20Res\% 20Rep\%20IDC\%206\%20soil\%20health\%20mapping.pdf (accessed 9 April 2018).

Wani, S.P., Chander, G. and Anantha, K.H. (2017) Enhancing resource use efficiency through soil management for improving livelihoods. In: Rakshit, A., Abhilash, P.C., Singh, H.B. and Ghosh, S. (eds) Adaptive Soil Management: From Theory to Practices. Springer, Singapore, pp. 413-451.

Wassmann, R., Neue, H.U., Lantin, R.S., Buendia, L.V. and Rennenberg, H. (2000) Characterization of methane emissions from rice fields in Asia. I. Comparison among field sites in five countries. Nutrient Cycling in Agroecosystems 58, 1-12.

Whitmore, A.P., Kirk, G.J.D. and Rawlins, B.G. (2014) Technologies for increasing carbon storage in soil to mitigate climate change. Soil Use and Management 31(S1), 62-71.

Zhang, G.H., Nearing, M.A. and Liu, B.Y. (2005) Potential effects of climate change on rainfall erosivity in the Yellow River basin of China. Transactions of the American Society of Agricultural Engineers 48, 511-517.

Zhang, F.S., Chen, X.P. and Vitousek, P. (2013) Chinese agriculture: an experiment for the world. Nature 497, 33-35. 